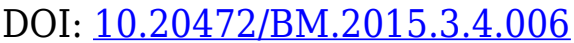

\title{
THE EFFECT OF DRIVERS GENDER ON THE PERCEPTION OF PORTUGUESE ROAD SAFETY COMMUNICATION CAMPAIGNS
}

\section{HELENA SOFIA RODRIGUES, MANUEL JOSÉ FONSECA, PAULO RIBEIRO CARDOSO}

\begin{abstract}
:
The road safety campaigns use a range of media and marketing communication techniques to alert drivers to take appropriate behavior on the road. The aim of this study was to investigate how gender differences influence the behavior and attitude of the Portuguese drivers regarding driving as well as the attitude toward the road safety campaigns. In Portugal, there are no studies that analyze the gender difference related to road safety, which reinforces its relevance. To implement this purpose, firstly it was described the profile of drivers by gender regarding a set of behavioral variables. The attitude of drivers toward the road safety communication campaigns was analyzed and drivers were grouped by clusters, aiming its characterization as possible targets of communication actions for road safety marketing.
\end{abstract}

\section{Keywords:}

Road traffic accidents; road safety campaigns; driver behavior; gender effect; target audience; Pearson Chi-Square; principal components analysis; cluster analysis

JEL Classification: M31, M37, C38

\section{Authors:}

HELENA SOFIA RODRIGUES, Business School, Polytechnic Institute of Viana do Castelo and CIDMA, University of Aveiro, Portugal, Email: sofiarodrigues@esce.ipvc.pt MANUEL JOSÉ FONSECA, Business School, Polytechnic Institute of Viana do Castelo - Applied Management Research Unit (UNIAG), Viana do Castelo, Portugal, Email: manuelfonseca@esce.ipvc.pt PAULO RIBEIRO CARDOSO, Faculty of Economic Sciences and Management, University Lusíada Porto and Faculty of Human and Social Sciences - University Fernando Pessoa, Porto, Portugal, Email: pjrcardoso@gmail.com

\section{Citation:}

HELENA SOFIA RODRIGUES, MANUEL JOSÉ FONSECA, PAULO RIBEIRO CARDOSO (2015). The effect of drivers gender on the perception of Portuguese road safety communication campaigns. International Journal of Business and Management, Vol. III(4), pp. 104-123., 10.20472/BM.2015.3.4.006 


\section{Introduction}

In Portugal, according to data provided by the National Road Safety Authority (ANSR, 2014) there were in 2014, 30,604 accidents with victims and 482 deaths. Traffic accidents are a global phenomenon with devastating social and economic consequences. The World Health Organization (WHO, 2009) annually accounts over than 1.3 million deaths (over 135,000 per day), estimating that this corresponds to an economic values between $1 \%$ and $3 \%$ of Gross Domestic Product of each country. Given the urgency of the problem, the United Nations General Assembly declared the period 2011-2020 as the "Decade of Action for Road Safety".

Worldwide, road crashes are responsible for $23 \%$ of deaths from external causes and are the leading cause of death in the age group 15 to 29 years. About $90 \%$ of deaths as a result of road accidents occur in low and middle income countries, which correspond to $2 / 3$ of the world population. The poorest and most vulnerable road users - pedestrians, cyclists and motorcyclists - are the main victims of road accidents in the world. Economically active adults aged 15 to 44 , are responsible for more than half of those killed in road accidents.

WHO stresses the fact that men are much more involved in road accidents than women, constituting $76 \%$ of fatalities. Given the evidence of numbers and according to the European Transport Safety Council (ETSC, 2013), 51\% of the total EU population are women, but only $24 \%$ of road deaths are females. Thus, gender differences should be recognized when developing road safety policies. Among the several procedures involved in fighting this reality - which is a multidisciplinary phenomenon - there are the communication campaigns of road safety. The recognition of the problem at European level is reflected in a number of initiatives which stands out most recently the Road Safety Program for 2011-2020 of the European Commission, with the overall purpose of reducing by $50 \%$ the number of deaths on European roads.

In Portugal it has been registered a progressive reduction of road accidents derived by a set of measures, such as the National Road Safety Plan (Plano Nacional de Prevenção Rodoviária, 2003) and the National Road Safety Strategy 2008-2015. Still, this is not transversal to all kinds of accidents and, it must be emphasized that every fatality is a social drama and a global burden estimated between 1 million and 1.5 million euros (Estratégia Nacional de Segurança Rodoviária, 2008).

The communication campaigns for road safety, as the object of study of this work, are assumed to be a form of direct combat to this multidisciplinary phenomenon. The marketing communication program appears itself referenced as an operational objective in the National Road Safety Strategy 2008-2015. This measure appears after being diagnosed, in the National Plan for Road Safety, that there is an insufficient coordination in promoting awareness campaigns for drivers. 
There is evidence that the main causes of road accidents are rooted in behavioral issues (road infractions), which should lead to additional efforts to inform, raise awareness and persuade. Finally, some studies point to the recognition of deficiencies in the strategic and tactical structuring process of the national road prevention campaigns: $68 \%$ of drivers said that communication campaigns within the road safety did not result (Reto and Sá, 2003) and, in 2005, the general secretary of the Portuguese Road Safety stressed that $97 \%$ of Portuguese did not feel influenced by this type of campaigns (Almeida, 2008 and Peixoto, 2006).

Given this context, it was defined as objective of this study to analyze the influence of gender (male and female) in the behavior of Portuguese drivers and their attitude towards driving, as well as their attitude towards the road safety campaigns. A survey to a sample of 310 national drivers was applied. First, the profile of drivers by gender using a set of behavioral variables is described, namely: driving profile, self-concept of risk, risky behavior on the road, involvement frequency in road accidents and attitude towards driving. Then, maintaining the logic of differentiation by gender, the attitude of drivers towards the Portuguese road safety communication campaigns was analyzed, as well as their personal involvement with the campaigns, the perceived effectiveness of these, the intention to act in accordance with the campaigns warnings and the recommendation of these safety measure to others. Finally, drivers were grouped per segments (cluster analysis), targeting its characterization as possible recipients of road safety marketing communication actions. Thus, this research work aims to advance the knowledge of this phenomenon in order to draw some paths for the future development of communication campaigns that can reduce risky behavior on the roads.

The paper is organizing as follows. Section 2 presents the conceptual framework of the gender dimension in the context of road safety. Section 3 describes the method applied to the empirical work, explaining the methodology used. In Section 4, results are analyzed and the typology of drivers is presented. Finally, some conclusions are highlighted in Section 5, namely related to the characterization of specific audiences (targeting) of road safety marketing communications campaigns and some possibilities for future research are suggested.

\section{Theoretical background}

The literature consistently shows that, although traffic accidents kill people from all age and gender groups, young aged people (mostly young men) are overrepresented in accident involvement. Additionally there are several studies that point to a significant difference between the behavioral profile of male and female drivers (National Road Safety Authority, 2014; European Transport Safety Council, 2013; Holland, Geraghty and Shah, 2010; Bener and Crundall, 2008; Oltedal and Rundmo, 2006; Ward and Lancaster 
and Ward, 2002; Anderson and Ingram, 2001; Shinar, Schechtman and Compton, 2001; Waller et al, 2001).

According to the National Road Safety Authority (2014) in the European Union, considering its 27 member states and based on statistical data from 2011, it can be stated that more than 30,400 people died on the roads as a result of collisions, where 23,200 victims correspond to the male gender. According to the report "Flash 25" of the ETSC (2013), males are much more likely to accidents than female members, hence the later occurrence of increased mortality in men (approximately 358,000 males and 113,000 females were killed in the EU 27 as a consequence of road collisions over the years 2001-2011). This difference is due mainly to the type of driving and consequently to greater exposure to risk by these drivers.

There is extensive evidence to show that men have a higher rate of collisions than women. In addition to having a higher number of collisions, men incur their first collision earlier in their driving career and are more likely than women to be held to blame for the incident. Female drivers are less prone to risky driving behavior, in particular speeding, and have more positive attitudes towards traffic regulations and safety (ETSC, 2013).

In Norway was also carried out a study with young drivers (Oltedal and Rundmo, 2006), where the authors try to understand the effects of personality traits and gender on risky driving behavior and accident involvement. However, the relations were not very strong, and the authors concluded through a regression analysis, that personality traits and gender were found to explain $37.3 \%$ of the variance in risky driving behavior.

Even in terms of personality, gender differences are significant. Holland, Geraghty and Shah (2010) have concluded that gender differences were found for dissociative, anxious, patient, risky, angry and high-velocity styles. In parallel, Turner and McClure (2003), in a study with 689 drivers have concluded through univariate analysis, that males scored higher means than females in driver aggression and thrill seeking and in their general risk acceptance. In addition, the authors used multivariate logistic regression analysis, and concluded that males were twice as likely to have reported at least one crash as a driver compared to females and nearly three times as likely to have reported two or more crashes.

In a study conducted in Turkey, Özkan and Lajunen (2006) state that young male drivers are also more prone to take risks, use seat belts more infrequently, engage in aggressive driving, speed and commit more violations than other age groups. They showed that perceptual-motor skills increased as a function of masculinity and being male (sex) while safety skills increased as a function of femininity. In addition they concluded that the feminine characteristics of the drivers might be used to promote safety-oriented general driving style, especially among young drivers.

In an attempt to explain the extent to which individual factors influence the driving behavior, Lancaster and Ward (2002) have found a number of differences between 
genders. So when it comes to men (the majority of aggressive drivers), those were involved in a greater number and more severe traffic accidents (among the 16-20 and 2124 age groups, the male population-based fatality rates were observed to be more than twice as high as those rates for females) and were more likely to have a traffic accident caused by violations. At the same time, men incurred violations sooner and had about twice the risk of committing an offence, and were less likely to use seat-belts. In a general way, women were more likely to be involved in crashes as a result of perceptual or judgmental errors and present a lower driving confidence.

The differences between men and women should be recognized and genderdifferentiated policies developed in relevant areas, mainly in the road safety communication campaigns. In Portugal, there are no studies that analyze the gender difference related to road safety, which reinforces the relevance of this work.

\section{Methodology}

As a method of gathering information particularly suitable for assessing livelihoods, social or family support, behavior, values, knowledge, expectations, opinions and attitudes in relation to options or human and social issues (Wimmer and Dominick, 1996 and Quivy and Campenhoudt, 2008), the survey allows, as this study is intended, to quantify a multitude of data for further analysis and relationship.

The use of the survey and quantitative analysis of the data through different techniques and statistical methods can be observed in a variety of research work carried out under the communication of road safety: Cardoso and Fonseca, 2012; Almeida, 2008; Bener and Crundall, 2008; Lewis, Watson and White, 2008; Lewis et al., 2007a; Mowen, Harris and Bone, 2004; Turner and McClure, 2003; Tay, 2002; Dobson et al., 1999.

\subsection{The survey design}

This study is part of the descriptive research design (Burns and Bush, 2006). The administered questionnaire included different scales of where we highlight the following informational objectives (Fonseca, 2012): 1) profile of drivers, with the information based on years of driving license, the driving frequency and the type of vehicle they drive; 2) self-concept of risk (Likert scale, classifying driving "not risky" to "extremely risky"), risky behavior on the road (scale created based on the main cause of accidents identified by the National Security Strategy road 2008-2015), frequency of involvement in traffic accidents (from "never" to "more than three times") and attitude towards driving (scale adapted from Almeida, 2008, with three dimensions: perceived benefits of adopting safe driving, individual control over the driving and Affective attitudes towards driving); 3) 
attitude towards the Portuguese road safety communication campaigns (scale adaptation Pollay and Mittal, 1993), personal involvement with the road safety communication campaigns (scale adaptation of Lewis, Watson and White, 2008), perceived effectiveness of campaigns road safety communication (scale adaptation of Lewis et al., 2007b) and intention to act according to the campaigns as well as intention to recommend to others the campaigns (built scale).

\subsection{The sample}

The sample that was taken is a convenient sample of drivers, rather than a random representative sample, due to time and budget constraints. However, the survey relied on the generation of a sample size large enough to generate meaningful data from the region. The respondents have between 18 to 65 years old and besides the criterion of having driving license, the individuals must have an active driving practice, not below once per month. The sample mirrors the population demographics reasonably. It was a clear concern to apply the survey to a similar composition by gender.

\subsection{Procedure}

A pre-test of 20 individuals was done and no anomalies or interpretation difficulties in filling the survey were observed. The procedure was to approach drivers and ask for their willingness to fill out the questionnaire anonymously. Questionnaires were completed by 350 individuals, with an average duration filling of 15 minutes. Only 310 were validated due to irregularities in filling. Fieldwork lasted about five weeks.

\section{Results and Discussion}

An analysis and discussion of the results was made, using a statistical approach through the software IBM SPSS version 22. Next subsection provides a description of the demographics characteristics of the drivers.

\subsection{Sample description}

In order to analyze the difference of gender there was a concern of having equilibrium of the sample related to gender: $50.6 \%$ of respondents are women and $49.4 \%$ are men, which mirrors the Portuguese population (INE, 2011). Table 1 shows the description of the respondents by age, education and professional situation. The respondents were divided into 5 categories of age. The average age is 34.83 and 37.78 , with a standard deviation is 0.84 and 1.01 for female and male samples, respectively. The weight of academic 
training in both gender are similar, having most of the respondents high school or an undergraduation completed. Besides, more than $70 \%$ have a job. It is possible to observe that the sample is balanced, giving a good bottom line for our analysis of gender of the questionnaire.

Table 1: Sample description by gender

\begin{tabular}{|c|c|c|c|c|}
\hline & & Female & Male & Total \\
\hline \multirow[t]{5}{*}{ Age } & $18-25$ & $21,0 \%$ & $20,3 \%$ & $20,6 \%$ \\
\hline & $26-35$ & $38,2 \%$ & $26,8 \%$ & $32,6 \%$ \\
\hline & $36-45$ & $24,2 \%$ & $25,5 \%$ & $24,8 \%$ \\
\hline & $46-55$ & $12,1 \%$ & $14,4 \%$ & $13,2 \%$ \\
\hline & $56-65$ & $12,1 \%$ & $14,4 \%$ & $13,2 \%$ \\
\hline \multicolumn{2}{|l|}{ Total } & $100,0 \%$ & $100,0 \%$ & $100,0 \%$ \\
\hline \multirow[t]{4}{*}{ Education } & Elementary School & $1,9 \%$ & $9,2 \%$ & $5,5 \%$ \\
\hline & High School & $34,4 \%$ & $37,3 \%$ & $35,8 \%$ \\
\hline & Undergraduate & $45,9 \%$ & $39,2 \%$ & $42,6 \%$ \\
\hline & Postgraduate / Master / PhD & $17,8 \%$ & $14,4 \%$ & $16,1 \%$ \\
\hline \multicolumn{2}{|l|}{ Total } & $100,0 \%$ & $100,0 \%$ & $100,0 \%$ \\
\hline \multirow[t]{5}{*}{ Employment status } & Student & $19,1 \%$ & $15,7 \%$ & $17,4 \%$ \\
\hline & Unemployed & $5,1 \%$ & $4,6 \%$ & $4,8 \%$ \\
\hline & Self-employed & $7,6 \%$ & $13,1 \%$ & $10,3 \%$ \\
\hline & Employed & $65,0 \%$ & $62,7 \%$ & $63,9 \%$ \\
\hline & Retired & $3,2 \%$ & $3,9 \%$ & $3,5 \%$ \\
\hline Total & & $100,0 \%$ & $100,0 \%$ & $100,0 \%$ \\
\hline
\end{tabular}

In order to have a better perception of the respondents' experience at road, it is also analyzed the driver profile in Table 2. The experience of female respondents has an average of 13,43 years with a standard deviation of 0,70 , while the male respondents have an average of 16,83 years of driving license with a standard deviation of 0,89 . There driving frequency is similar to both gender and the majority drives every day. More than $80 \%$ of the inquiries drive a passenger car.

Table 2: Driver profile by gender

\begin{tabular}{llrrr}
\hline & & Female & Male & Total \\
\hline Years of driving & $0-5$ & $18,5 \%$ & $22,2 \%$ & $20,3 \%$ \\
license & $6-10$ & $21,0 \%$ & $9,2 \%$ & $15,2 \%$ \\
& $11-20$ & $43,9 \%$ & $35,3 \%$ & $39,7 \%$ \\
& $21-30$ & $11,5 \%$ & $20,9 \%$ & $16,1 \%$ \\
& $30-40$ & $5,1 \%$ & $12,4 \%$ & $8,7 \%$ \\
\hline Total & & $100,0 \%$ & $100,0 \%$ & $100,0 \%$ \\
\hline
\end{tabular}




\begin{tabular}{|c|c|c|c|c|}
\hline \multirow[t]{4}{*}{ Driving frequency } & Once a month & $5,7 \%$ & $0,7 \%$ & $3,2 \%$ \\
\hline & Once a week & $4,5 \%$ & $5,2 \%$ & $4,8 \%$ \\
\hline & Three times a week & $10,2 \%$ & $12,4 \%$ & $11,3 \%$ \\
\hline & Everyday & $79,6 \%$ & $81,7 \%$ & $80,6 \%$ \\
\hline Total & & $100,0 \%$ & $100,0 \%$ & $100,0 \%$ \\
\hline \multirow[t]{5}{*}{ Type of vehicle } & Passenger car & $87,3 \%$ & $81,7 \%$ & $84,5 \%$ \\
\hline & Commercial vehicle & $10,8 \%$ & $8,5 \%$ & $9,7 \%$ \\
\hline & Motorcycle up $125 \mathrm{~cm}^{3}$ & $0,6 \%$ & $2,0 \%$ & $1,3 \%$ \\
\hline & Motorcycle more than $125 \mathrm{~cm}^{3}$ & $0,6 \%$ & $3,3 \%$ & $1,9 \%$ \\
\hline & Trunk & $0,6 \%$ & $4,6 \%$ & $2,6 \%$ \\
\hline Total & & $100,0 \%$ & $100,0 \%$ & $100,0 \%$ \\
\hline
\end{tabular}

\subsection{Driving behavior}

A second part of the survey is concerned with the driving behavior: each interviewed gave the evaluation about its own driving behavior, related to risks taken, legal infringements and attitudes towards road safety communication campaigns.

\subsubsection{Driving profile}

Table 3 is concerned with the perception of the driver relative to the risks taken on the road. This item uses a five-level Likert scale to make the classification, from not risky to extremely risky. Comparing the percentage between genders is possible to say that women consider their driving less risky. With the nonparametric Pearson Chi-Square test of independence, is possible to confirm that this difference is statistically significant (sig=0.009) for all usually significant levels used. Notice that all assumptions to the reliability of the test were fulfilled, which means that at least 80 per cent of cells should have expected frequencies of 5 or more and the lowest expected frequency in any cell should be 1 (see Pallant, 2005 for more details). In the following tables, if nothing is said, this means that all assumptions were fulfilled.

Table 3: Self-concept of risk

\begin{tabular}{llrrr}
\hline & & Female & Male & Total \\
\hline Self-concept of risk & Not risky & $35,0 \%$ & $22,2 \%$ & $28,7 \%$ \\
& A little risky & $56,7 \%$ & $60,8 \%$ & $58,7 \%$ \\
& Risky & $8,3 \%$ & $17,0 \%$ & $12,6 \%$ \\
& Very risky & $0 \%$ & $0 \%$ & $0 \%$ \\
Total & Extremely risky & $0 \%$ & $0 \%$ & $100,0 \%$ \\
\hline \multirow{2}{*}{ Pearson Chi-Square } & & $100,0 \%$ & $100,0 \%$ & \\
\hline
\end{tabular}

a. 0 cells $(0,0 \%)$ have expected count less than 5 . The minimum expected count is 19,25 
The importance of this analysis lies in the relationship of this self-concept with the attitude to communication campaigns to promote road safety. Some studies refer that there is tendency to assign blame to others (Reto and Sá, 2003 and Marques, 2011). If there are no failure or limitation recognitions, there is no predisposition to change, and therefore, the receptivity to communications campaigns is low.

Table 4 reports some risks behaviors that are known as accident causes. The respondents focused their answers in first three level of the Likert scale, assuming the male gender a lightly more risky behavior. This difference is only statistically significant for speed limit and driving after drink alcohol, as proved by Pearson Chi-Square test (sig=0.003 and sig=0,001, respectively) for any usual significance level.

Table 4: Risk behaviors in driving

\begin{tabular}{|c|c|c|c|c|c|c|c|}
\hline Item & & Never & Rarely & Sometimes & $\begin{array}{l}\text { Most of } \\
\text { the time }\end{array}$ & Always & Pearson Chi-Square \\
\hline \multirow{2}{*}{$\begin{array}{l}\text { Exceed the legal } \\
\text { speed limits }\end{array}$} & Female & $8,9 \%$ & $35,7 \%$ & $41,4 \%$ & $14,0 \%$ & $0,0 \%$ & \multirow{2}{*}{$\begin{array}{l}\text { Value }=15,863 ; \mathrm{df}=4 \\
\text { Sig }=0,003\end{array}$} \\
\hline & Male & $5,9 \%$ & $22,2 \%$ & $44,4 \%$ & $23,5 \%$ & $3,9 \%$ & \\
\hline \multirow{2}{*}{$\begin{array}{l}\text { Driving after drink } \\
\text { alcohol }\end{array}$} & Female & $55,4 \%$ & $33,8 \%$ & $7,6 \%$ & $3,2 \%$ & $0,0 \%$ & \multirow{2}{*}{$\begin{array}{l}\text { Value }=18,842 ; \mathrm{df}=4 \\
\text { Sig }=0,001\end{array}$} \\
\hline & Male & $35,3 \%$ & $39,2 \%$ & $18,3 \%$ & $4,6 \%$ & $2,6 \%$ & \\
\hline \multirow{2}{*}{$\begin{array}{l}\text { Use cell phone } \\
\text { while driving without } \\
\text { hands free device }\end{array}$} & Female & $26,1 \%$ & $45,9 \%$ & $21,0 \%$ & $6,4 \%$ & $0,6 \%$ & \multirow{2}{*}{$\begin{array}{l}\text { Value }=2,184 ; d f=4 \\
\text { Sig }=0,702\end{array}$} \\
\hline & Male & $24,8 \%$ & $41,2 \%$ & $23,5 \%$ & $8,5 \%$ & $2,0 \%$ & \\
\hline
\end{tabular}

About $65 \%$ have already had at least one accident, in both genders (see Table 5). The difference between genders is only statistically significant when it is used $5 \%$ or more of significance level.

Table 5: Traffic accidents

\begin{tabular}{|c|c|c|c|c|c|c|c|}
\hline & & Never & Once & Twice & $\begin{array}{l}\text { Three } \\
\text { times }\end{array}$ & $\begin{array}{l}\text { More } \\
\text { than } \\
\text { three } \\
\text { times }\end{array}$ & $\begin{array}{l}\text { Pearson } \\
\text { Chi-Square }\end{array}$ \\
\hline \multirow{2}{*}{ Traffic accident } & Female & $35,0 \%$ & $34,4 \%$ & $21,7 \%$ & $5,7 \%$ & $3,2 \%$ & \multirow{2}{*}{$\begin{array}{l}\text { Value }=10,895 ; \mathrm{df}=4 \\
\text { Sig }=0,028\end{array}$} \\
\hline & Male & $35,9 \%$ & $25,5 \%$ & $17,6 \%$ & $10,5 \%$ & $10,5 \%$ & \\
\hline
\end{tabular}

\subsubsection{Attitude towards driving}

The analysis of attitude towards driving is made in Table 6. These attitudes are evaluated through three dimensions: perceived benefits of adopting safe driving, individual control over the driving and affective attitudes towards driving. All the questions were classified 
by a five-level Likert scale: 1 means "Strongly Disagree" and 5 means "Strongly Agree". The respondents consider that there are benefits to adopt a safe driving, according to the high scores for female and male answers. At the same time, the drivers feel that have an individual control over their driving, differentiating the safe and risky type of driving. Finally, they have an affective attitude towards driving, which means that they feel well when they respect the Highway Code.

For most of the items, the female average is higher than the male average, which is with agreement with the self-concept of risky inquired before. However, this difference is not statistically significant when $5 \%$ of significance level is considered, except for the item "I like to drive respecting the Highway Code". Besides, in the Pearson Chi-Square test that has $\left({ }^{*}\right)$, the assumptions were violated, which weakens the reliability of the conclusions.

Table 6: Attitudes towards driving (1=Strongly Disagree / 5=Strongly Agree)

\begin{tabular}{|c|c|c|c|c|c|}
\hline Dimensions & Items & Gender & Mean & St.Dev & Pearson Chi-Square \\
\hline \multirow{8}{*}{$\begin{array}{l}\text { Perceived benefits } \\
\text { of adopting safe } \\
\text { driving }\end{array}$} & \multirow{2}{*}{$\begin{array}{l}\text { The respect for the Highway Code } \\
\text { prevents traffic accidents. }\end{array}$} & Female & 4,51 & 0,05 & \multirow{2}{*}{$\begin{array}{l}\text { Value }=7,778 ; d f=4 \\
\text { Sig }=0,100\left(^{*}\right)\end{array}$} \\
\hline & & Male & 4,33 & 0,06 & \\
\hline & \multirow{2}{*}{ It is beneficial to respect the traffic rules. } & Female & 4,62 & 0,04 & \multirow{2}{*}{$\begin{array}{l}\text { Value }=2,143 ; d f=3 \\
\text { Sig }=0,543\left(^{*}\right)\end{array}$} \\
\hline & & Male & 4,54 & 0,05 & \\
\hline & \multirow{2}{*}{$\begin{array}{l}\text { The respect for traffic rules is effective } \\
\text { in the prevention of road accidents. }\end{array}$} & Female & 4,44 & 0,05 & \multirow{2}{*}{$\begin{array}{l}\text { Value }=9,490 ; \mathrm{df}=4 \\
\mathrm{Sig}=0,050\left(^{*}\right)\end{array}$} \\
\hline & & Male & 4,25 & 0,07 & \\
\hline & \multirow{2}{*}{$\begin{array}{l}\text { The respect for traffic rules prevents my } \\
\text { engagement in road accidents. }\end{array}$} & Female & 4,25 & 0,07 & \multirow{2}{*}{$\begin{array}{l}\text { Value }=4,599 ; d f=4 \\
\text { Sig }=0,331\end{array}$} \\
\hline & & Male & 4,07 & 0,08 & \\
\hline \multirow{8}{*}{$\begin{array}{l}\text { Individual control } \\
\text { over the driving }\end{array}$} & \multirow{2}{*}{$\begin{array}{l}\text { When I drive, I can decide if I have a } \\
\text { safe driving type or risky type. }\end{array}$} & Female & 4,16 & 0,06 & \multirow{2}{*}{$\begin{array}{l}\text { Value }=1,120 ; \mathrm{df}=3 \\
\text { Sig }=0,772\end{array}$} \\
\hline & & Male & 4,20 & 0,06 & \\
\hline & \multirow{2}{*}{$\begin{array}{l}\text { I believe I can make decisions about the } \\
\text { type of driving that I should take (safe or } \\
\text { risky). }\end{array}$} & Female & 4,33 & 0,05 & \multirow{2}{*}{$\begin{array}{l}\text { Value }=3,236 ; \mathrm{df}=3 \\
\text { Sig }=0,357\end{array}$} \\
\hline & & Male & 4,21 & 0,06 & \\
\hline & \multirow{2}{*}{ If I don't feel able to drive, I will not do. } & Female & 4,50 & 0,06 & \multirow{2}{*}{$\begin{array}{l}\text { Value }=3,109 ; \mathrm{df}=4 \\
\text { Sig }=0,540\left(^{*}\right)\end{array}$} \\
\hline & & Male & 4,42 & 0,07 & \\
\hline & \multirow{2}{*}{$\begin{array}{l}\text { I feel I control my driving type (safe or } \\
\text { risky). }\end{array}$} & Female & 4,26 & 0,07 & \multirow{2}{*}{$\begin{array}{l}\text { Value }=2,817 ; \mathrm{df}=4 \\
\text { Sig }=0,589\end{array}$} \\
\hline & & Male & 4,18 & 0,09 & \\
\hline \multirow{7}{*}{$\begin{array}{l}\text { Affective attitudes } \\
\text { towards driving }\end{array}$} & \multirow{2}{*}{$\begin{array}{l}\text { I feel good when I drive respecting the } \\
\text { Highway Code. }\end{array}$} & Female & 4,31 & 0,06 & \multirow{2}{*}{$\begin{array}{l}\text { Value }=4,462 ; \mathrm{df}=4 \\
\text { Sig }=0,347\end{array}$} \\
\hline & & Male & 4,14 & 0,07 & \\
\hline & \multirow{2}{*}{$\begin{array}{l}\text { The persons that drive respecting the } \\
\text { Highway Code are more responsible. }\end{array}$} & Female & 4,22 & 0,07 & \multirow{2}{*}{$\begin{array}{l}\text { Value }=9,279 ; \mathrm{df}=4 \\
\text { Sig }=0,054\end{array}$} \\
\hline & & Male & 3,91 & 0,09 & \\
\hline & \multirow{3}{*}{$\begin{array}{l}\text { I like to drive respecting the Highway } \\
\text { Code. }\end{array}$} & Female & 4,50 & 0,06 & \multirow{3}{*}{$\begin{array}{l}\text { Value }=11,543 ; \mathrm{df}=4 \\
\text { Sig }=0,021\end{array}$} \\
\hline & & Male & 4,27 & 0,08 & \\
\hline & & Male & 3,58 & 0,10 & \\
\hline
\end{tabular}

\subsection{Attitude towards the Portuguese road safety communication campaigns}

In this point, it is analyzed the general attitude of drivers towards the road safety campaigns (see Table 7). In spite of the opinion presents on average, positive scores, 
these values are not clearly expressive. The attitude is similar for both genders, corroborated by the test of independence.

In the same way, was asked to drivers about the relevance of these campaigns for them and for their driving: once again, the values on average were positive, but not overwhelming. According to Lewis, Watson and White (2008), one of the aspects that determine the effectiveness of road safety advertising messages, in terms of persuasion capacity, is the individual involvement degree.

Table 7: General attitude towards communication campaigns about road safety (1=Strongly Disagree / 5=Strongly Agree)

\begin{tabular}{|c|c|c|c|c|c|}
\hline Dimensions & Items & Gender & Mean & St.Dev & Pearson Chi-Square \\
\hline \multirow{6}{*}{$\begin{array}{l}\text { General attitude } \\
\text { towards } \\
\text { campaigns }\end{array}$} & \multirow{2}{*}{$\begin{array}{l}\text { In general, I like the Portuguese road } \\
\text { safety communication campaigns. }\end{array}$} & Female & 3,73 & 0,06 & \multirow{2}{*}{$\begin{array}{l}\text { Value }=7,647 ; \mathrm{df}=4 \\
\text { Sig }=0,105\end{array}$} \\
\hline & & Male & 3,52 & 0,07 & \\
\hline & \multirow{2}{*}{$\begin{array}{l}\text { My general opinion about this } \\
\text { campaigns is favorable. }\end{array}$} & Female & 3,80 & 0,06 & \multirow{2}{*}{$\begin{array}{l}\text { Value }=7,930 ; \mathrm{df}=4 \\
\text { Sig }=0,094\end{array}$} \\
\hline & & Male & 3,69 & 0,08 & \\
\hline & \multirow{2}{*}{$\begin{array}{l}\text { In general, I consider Portuguese road } \\
\text { safety communication campaigns a nice } \\
\text { thing. }\end{array}$} & Female & 3,83 & 0,06 & \multirow{2}{*}{$\begin{array}{l}\text { Value }=3,321 ; \mathrm{df}=4 \\
\text { Sig }=0,506\end{array}$} \\
\hline & & Male & 3,75 & 0,07 & \\
\hline \multirow{2}{*}{$\begin{array}{l}\text { Personal } \\
\text { involvement with } \\
\text { campaigns }\end{array}$} & \multirow{2}{*}{$\begin{array}{l}\text { The campaigns are relevant for me and } \\
\text { for my driving. }\end{array}$} & Female & 3,48 & 0,07 & \multirow{2}{*}{$\begin{array}{l}\text { Value }=3,771 ; d f=4 \\
\text { Sig }=0,438\end{array}$} \\
\hline & & Male & 3,32 & 0,08 & \\
\hline
\end{tabular}

Following the above questions is necessary to verify if these campaigns are considered effective by the respondents. The results are in Table 8 and it is possible to observe that the drivers consider the campaigns persuasive, convincing, effective and appealing. However, the results are lower when it is evaluated the memorability of the campaigns; so, this fact could be explained by the temporary effect of the campaigns, without a long term effect on the drivers memory. The female drivers tend to valorize more the campaigns when compared to the male drivers, once the scores are higher in every item analyzed. Besides, the last item of the table is statistically different for the subsets considered: the women remember more the campaigns, given a positive value to the item, while the men give a negative score to this item (sig=0,018, which mean that this difference is statistically significant for $5 \%$ ). This difference can be an important tool for the future: if the target audience remembers differently the road safety campaigns, the development of new campaigns should take this factor into account, in order to be more effective for both genders. As referred Delhomme et al. (2009), practices that have been evaluated as effective in previous high-quality projects can provide useful input for planning new programs. 
Table 8: Perceived efficacy about road safety campaigns (1=Strongly Disagree / 5=Strongly Agree)

\begin{tabular}{|c|c|c|c|c|c|}
\hline Dimensions & Items & Gender & Mean & St.Dev & Pearson Chi-Square \\
\hline \multirow{10}{*}{$\begin{array}{l}\text { Perceived efficacy } \\
\text { of the road safety } \\
\text { campaigns }\end{array}$} & \multirow{2}{*}{$\begin{array}{l}\text { Given my behavior on the road, the } \\
\text { campaigns are persuasive. }\end{array}$} & Female & 3,38 & 0,07 & Value $=3,444 ; \mathrm{df}=4$ \\
\hline & & Male & 3,25 & 0,07 & Sig $=0,486$ \\
\hline & \multirow{2}{*}{$\begin{array}{l}\text { For me, these campaigns are } \\
\text { convincing. }\end{array}$} & Female & 3,45 & 0,07 & Value $=2,109 ; \mathrm{df}=4$ \\
\hline & & Male & 3,35 & 0,07 & Sig $=0,716$ \\
\hline & \multirow{2}{*}{$\begin{array}{l}\text { As driver, I consider the campaigns } \\
\text { effective. }\end{array}$} & Female & 3,37 & 0,07 & Value $=4,767 ; \mathrm{df}=4$ \\
\hline & & Male & 3,22 & 0,08 & Sig $=0,312$ \\
\hline & \multirow{2}{*}{$\begin{array}{l}\text { As driver, I can say that these } \\
\text { campaigns are appealing. }\end{array}$} & Female & 3,48 & 0,07 & Value $=5,831 ; \mathrm{df}=4$ \\
\hline & & Male & 3,28 & 0,08 & Sig $=0,212$ \\
\hline & \multirow{2}{*}{ For me, the campaigns are memorable. } & Female & 3,15 & 0,08 & Value $=11,900 ; \mathrm{df}=4$ \\
\hline & & Male & 2,78 & 0,08 & Sig $=0,018$ \\
\hline
\end{tabular}

Finally, the intention of act according to the road safety campaigns, as well as to recommend them is analyzed in Table 9. The respondents claim that they follow the advices presented in the campaigns. Consistent with this attitude, they also recommend those advices to friends, their family members and others persons. Once again the average of answers given by the female respondents is higher than the men, which is consistent with previous answers about risks taken and efficacy of the road safety campaigns. The difference between genders is only statistically significant in the intention to act according to the campaigns.

Table 9: Predisposition to act according to the road safety campaigns and to recommend to others (1=Strongly Disagree / $5=$ Strongly Agree)

\begin{tabular}{|c|c|c|c|c|c|}
\hline Dimensions & Items & Gender & Mean & St.Dev & Pearson Chi-Square \\
\hline \multirow{6}{*}{$\begin{array}{l}\text { Intention to act } \\
\text { according to the } \\
\text { campaigns }\end{array}$} & \multirow{2}{*}{$\begin{array}{l}\text { When I see these campaigns, I follow } \\
\text { the advices that are presented. }\end{array}$} & Female & 3,62 & 0,05 & \multirow{2}{*}{$\begin{array}{l}\text { Value }=12,928 ; \mathrm{df}=4 \\
\text { Sig }=0,012\end{array}$} \\
\hline & & Male & 3,43 & 0,07 & \\
\hline & \multirow{2}{*}{$\begin{array}{l}\text { I comply with the advices in my daily } \\
\text { journey. }\end{array}$} & Female & 3,78 & 0,05 & \multirow{2}{*}{$\begin{array}{l}\text { Value }=18 ; 909 \mathrm{df}=4 \\
\text { Sig }=0,001\end{array}$} \\
\hline & & Male & 3,47 & 0,08 & \\
\hline & \multirow{2}{*}{$\begin{array}{l}\text { When I drive, I practice the given } \\
\text { advices by the road safety campaigns. }\end{array}$} & Female & 3,72 & 0,06 & \multirow{2}{*}{$\begin{array}{l}\text { Value }=13,668 ; d f=4 \\
\text { Sig }=0,008\end{array}$} \\
\hline & & Male & 3,42 & 0,08 & \\
\hline \multirow{6}{*}{$\begin{array}{l}\text { Intention to } \\
\text { recommend to } \\
\text { others the } \\
\text { campaigns }\end{array}$} & \multirow{2}{*}{ I give those advices to my relatives. } & Female & 3,65 & 0,07 & \multirow{2}{*}{$\begin{array}{l}\text { Value }=7,325 ; \mathrm{df}=4 \\
\text { Sig }=0,120\end{array}$} \\
\hline & & Male & 3,40 & 0,08 & \\
\hline & \multirow{2}{*}{ I advertise this advice to others } & Female & 3,50 & 0,07 & \multirow{2}{*}{$\begin{array}{l}\text { Value }=6,815 ; \mathrm{df}=4 \\
\text { Sig }=0,146\end{array}$} \\
\hline & & Male & 3,29 & 0,08 & \\
\hline & \multirow{2}{*}{$\begin{array}{l}\text { If a friend fits into a situation presented } \\
\text { in the campaigns, I give the advice } \\
\text { expressed therein. }\end{array}$} & Female & 3,56 & 0,06 & \multirow{2}{*}{$\begin{array}{l}\text { Value }=6,704 ; \mathrm{df}=4 \\
\text { Sig }=0,152\end{array}$} \\
\hline & & Male & 3,54 & 0,07 & \\
\hline
\end{tabular}




\subsection{Principal Components Analysis and Cluster Analysis}

The final aim of this subsection is to form clusters in order to study the best message strategy to aid campaign designers in tailoring the message to fit the target audience's characteristics and the communication context in which it will be received.

For this clusters analysis four dimensions related with the driving behavior were selected: risk behavior on the road, perceived benefit of the adoption of safe driving, individual control over the driving and affective attitudes to driving. At this moment, is important the evaluation of reliability of the questionnaire. To measure the accuracy of the data interpretation, the Alpha's Cronbach is used. This value ranges between 0 and 1, and an internal consistency is considered reasonable above 0.6 (see George and Mallery, 2003, for more details). In situations where this value is too low, it is suggested the elimination of some items of the questionnaire, without loss of information about a latent variable, in order to increase the internal consistency. For this study, it was necessary to eliminate two items of the individual control dimension to increase the internal consistency. In this way, for the four dimensions studied the values obtained are 0.620, 0.837, 0.804 and 0.672 , respectively. This led us to a reasonable internal consistency to our study.

As each dimension has several items, that have a high degree of correlation between them, a principal analysis of components (PCA) was done. Principal components is essentially a method of data reduction that aims to produce a small number of derived variables that can be used in place of the larger number of original variables to simplify subsequent analysis of the data.

For this principal analysis of components, the Kaiser criterion - related with the selection of components that have eigenvalues higher than unity - was selected (see Landau and Everitt, 2004 for more details). In this way, a new variable arises to describe each dimension, as presented in Table 10.

The Kaiser-Meyer-Olkin measure of sampling adequacy indicates the proportion of variance of the variables that might be caused by underlying factors. High values, close to one, generally indicate that a factor analysis is useful to the data. If the value is less than 0.50, the results of the factor analysis are not useful. Our results, are not overwhelming, but allow continuing the analysis. Besides, the Bartlett's test of sphericity, that tests the hypothesis if the items being independent among them, has $p$ value 0,000 for all dimensions and consequently states that the variables are correlated, which gives more confidence in proceed the PCA.

The communalities represent the percentage of variability attributed to the model that can be explained by the factors. Most of the values obtained are greater than 0,60 , giving a good variance of data explained. The sixth column is related to the variance explained by only one component for each dimension: it is not the desirable but the increase of components at this stage will lead to an increase of data for our cluster analysis that is our final goal. 
Table 10: Principal analysis of components for driving behavior

\begin{tabular}{|c|c|c|c|c|c|c|}
\hline $\begin{array}{l}\text { Dimension/New } \\
\text { variable }\end{array}$ & Item & $\begin{array}{l}\mathrm{KMO} \\
\text { test }\end{array}$ & $\begin{array}{l}\text { Bartlett } \\
\text { test }\end{array}$ & $\begin{array}{l}\text { Communalities } \\
\text { after extraction }\end{array}$ & $\begin{array}{l}\text { Total } \\
\text { variation } \\
\text { explained }\end{array}$ & $\begin{array}{l}\text { Component } \\
\text { (Weights) }\end{array}$ \\
\hline \multirow[t]{3}{*}{ Risk behavior } & Exceed the legal speed limit & \multirow{3}{*}{0,641} & \multirow{3}{*}{$\begin{array}{l}\text { Sig }= \\
=0.000\end{array}$} & 0,580 & \multirow{3}{*}{$56,86 \%$} & 0,762 \\
\hline & Driving after drink alcohol & & & 0,522 & & 0,723 \\
\hline & $\begin{array}{l}\text { Use cell phone while driving } \\
\text { without hands free device }\end{array}$ & & & 0,603 & & 0,777 \\
\hline \multirow{4}{*}{$\begin{array}{l}\text { Perceived } \\
\text { benefits of } \\
\text { adopting safe } \\
\text { driving }\end{array}$} & $\begin{array}{l}\text { The respect for the Highway } \\
\text { Code prevents traffic accidents. }\end{array}$ & \multirow{4}{*}{,796 } & \multirow{4}{*}{$\begin{array}{l}\text { Sig }= \\
=0.000\end{array}$} & 0,796 & \multirow{4}{*}{$69,19 \%$} & 0,892 \\
\hline & $\begin{array}{l}\text { It is beneficial to respect the } \\
\text { traffic rules. }\end{array}$ & & & 0,583 & & 0,764 \\
\hline & $\begin{array}{l}\text { The respect for traffic rules is } \\
\text { effective in the prevention of } \\
\text { road accidents. }\end{array}$ & & & 0,755 & & 0,869 \\
\hline & $\begin{array}{l}\text { The respect for traffic rules } \\
\text { prevents my engagement in road } \\
\text { accidents. }\end{array}$ & & & 0,633 & & 0,796 \\
\hline
\end{tabular}

\begin{tabular}{|c|c|c|c|c|c|c|}
\hline $\begin{array}{l}\text { Individual } \\
\text { control over the } \\
\text { driving }\end{array}$ & $\begin{array}{l}\text { When I drive, I can decide if I } \\
\text { have a safe driving type or risky } \\
\text { type. }\end{array}$ & 500 & Sig $=$ & 0,838 & $8376 \%$ & 0,915 \\
\hline & $\begin{array}{l}\text { I believe I can make decisions } \\
\text { about the type of driving that I } \\
\text { should take (safe or risky). }\end{array}$ & , & $=0.000$ & 0,838 & & 0,915 \\
\hline
\end{tabular}

\begin{tabular}{|c|c|c|c|c|c|c|}
\hline \multirow{4}{*}{$\begin{array}{l}\text { Affective } \\
\text { attitudes } \\
\text { towards driving }\end{array}$} & $\begin{array}{l}\text { I feel good when I drive } \\
\text { respecting the Highway Code. }\end{array}$ & \multirow{4}{*}{, 589} & \multirow{4}{*}{$\begin{array}{c}\text { Sig }= \\
=0.000\end{array}$} & 0,716 & \multirow{4}{*}{$58,26 \%$} & 0,846 \\
\hline & $\begin{array}{l}\text { The persons that drive } \\
\text { respecting the Highway Code } \\
\text { are more responsible. }\end{array}$ & & & 0,637 & & 0,798 \\
\hline & Driving respecting the Highway & & & & & \\
\hline & $\begin{array}{l}\text { Code can decrease my driving } \\
\text { pleasure. }\end{array}$ & & & 0,395 & & $-0,628$ \\
\hline
\end{tabular}

One of assumptions of the clusters analysis is the lower correlation between variables, in order to have more discriminant power to create subgroups that are more manageable than individual data. Table 11 shows that maximum correlation is obtained by "perceived benefits of adopting a safe driving" and "affective attitudes towards driving". All the others, present values closer to zero. 
Table 11: Correlation results for the new variables

\begin{tabular}{lccc}
\hline & Risk behavior & $\begin{array}{c}\text { Perceived benefits } \\
\text { of adopting safe } \\
\text { driving }\end{array}$ & $\begin{array}{c}\text { Individual control } \\
\text { over the driving }\end{array}$ \\
\hline $\begin{array}{l}\text { Perceived benefits of adopting safe } \\
\text { driving }\end{array}$ &,$- 308^{* *}$ & \\
\hline Individual control over the driving &, 005 &, $122^{*}$ &, $149^{* *}$ \\
\hline Affective attitudes towards driving &,$- 444^{* *}$ & & \\
\hline${ }^{*}$. Correlation is significant at the level 0,05 (2-tailed) & \\
${ }^{* *}$. Correlation is significant at the level 0,01 (2-tailed)
\end{tabular}

Finally, it is presented a cluster analysis, using non-hierarchical method. There were made distinct extractions, using different number of clusters. The most equilibrated clusters correspondents to three different groups that were denominated as unconscious risky (cluster 1), conscious risky (cluster 2) and carefully (cluster 3 ). The final values for the centers of the clusters are in Table 12.

Table 12: Center of the clusters

\begin{tabular}{lccc}
\hline & \multicolumn{3}{c}{ Cluster } \\
\cline { 2 - 4 } & $\begin{array}{c}1 \\
\text { (unconscious risky) }\end{array}$ & $\begin{array}{c}\text { (conscious } \\
\text { risky) }\end{array}$ & (carefully) \\
\hline Risk behavior & &,- 02382 &,- 37501 \\
\hline Perceived benefits of adopting safe driving & 1,66446 &,- 21505 &, 60978 \\
\hline Individual control over the driving & $-1,47030$ &,- 68510 &, 75330 \\
\hline Affective attitudes towards driving &, 22669 &,- 23031 &, 68551 \\
\hline
\end{tabular}

Analyzing the number of individuals that are members of each cluster is possible to observe that female respondents assume features that fit in carefully behavior, whereas male individual presents characteristics with more risk. Even so, both genders have a low number of individuals in the unconscious risky cluster (Table 13).

Table 13: Number of members in each cluster, by gender

\begin{tabular}{lccc}
\hline & \multicolumn{3}{c}{ Cluster } \\
\cline { 2 - 4 } & (unconscious risky) & $\begin{array}{c}2 \\
\text { (conscious } \\
\text { risky) }\end{array}$ & $\begin{array}{c}3 \\
\text { (carefully) }\end{array}$ \\
\hline Female & $7(22,6 \%)$ & $72(49,0 \%)$ & $78(59,1 \%)$ \\
\hline Male & $24(77,4 \%)$ & $75(51,0 \%)$ & $54(40,9 \%)$ \\
\hline Total & $31(10,0 \%)$ & $147(47,4 \%)$ & $132(42,6 \%)$ \\
\hline
\end{tabular}

Taking into account the results obtained in Table 13 as a high number of individuals that are members of the risky clusters, the road safety campaigns still have challenges to 
overcome. In order to improve future campaigns, and because the resources are always scarce, it is necessary to identify the key elements that contribute to making a road safety communication campaign successful.

\section{Conclusions and recommendations}

Road safety communication campaigns often rely on a variety of means and tools. However, to be effective, the strategy message should be targeted to a specific audience. In this paper, the effects of road safety campaigns on Portuguese drivers were analyzed according to the gender.

The female drivers have less risky behaviors, namely speeding and driving after drink. The clusters analysis corroborates the inclusion of more men in the risky compartments. Besides, women remember better the road safety campaigns and intend to apply that safety measure in the daily journey, when compared to the men answers. For these reasons, the gender segmentation could/should be taken as a key success factor when the target audience for the next road safety communication campaigns is considered.

In order to fight this problem, the education of children (future drivers, passengers and pedestrians), must be strongly implemented, taking into account that school education is crucial to the passage of knowledge and awareness among future drivers.

The results of this study are important for marketing and communication professionals involved in carrying out road safety campaigns. Based on the data obtained, and in the context of these campaigns, it is suggested a strategy on two fronts. As an initial objective, generic campaigns directed at both groups should be carried out. These campaigns should concentrate on warning for risky behavior on the road observed in both genres, including the use of mobile phones while driving. Such campaigns should be inserted in general media, which can reach the two groups.

As a second approach, it is proposed the development of campaigns targeting especially the male audience, as it stands out as a group that has more risk behavior on the roads. In this sense, it is suggested to build messages with specific content, such as warning for speeding or driving under the influence of alcohol. These campaigns could also be inserted in specific media targeted to the male audience, particularly newspapers, magazines and television programs especially consumed by these public.

This work opens the way for future research involving the development of road safety campaigns. In future studies can be deepened the profile of each group, men and women, with regard to their media consumption habits in order to create a preferred map for inserting the campaigns.

Another research field that can be explored is to investigate the most appropriate content for each of the groups. This can be carried out using messages previously constructed and the experimental method as methodological approach. 
As a final note remains to note that road safety campaigns appear to play a key role in raising awareness and behavioral change. Still, the mortality rate among young people, especially males, remains very high and worrying. The use of specific target campaigns for this audience is crucial.

Only truly targeted and focused policies for citizens can reduce the incredibly high numbers that still haunt the European Union and Portugal in particular, despite the effort and the positive trend we have been experiencing in these last two decades.

\section{Acknowledgements}

This work was supported by The Portuguese Foundation for Science and Technology (FCT), through CIDMA within project PEst-OE/MAT/UI4106/2014 (Rodrigues).

\section{References}

ALMEIDA, I. (2008). Master thesis - Os apelos ao medo nas campanhas de prevenção rodoviária: as reacções dos jovens universitários. Lisboa, Instituto Superior de Economia e Gestão, Universidade Técnica de Lisboa.

ANDERSON, S. and INGRAM, D. (2001). Drinking and Driving: prevalence, decision-making and attitudes. NFO System Three Social Research. Development Department Research Programme. Research Findings No. 128. Scottish Executive Central Research Unit.

ANSR (Autoridade Nacional de Segurança Rodoviária), Artigos Técnicos 2014, http:// http://www.ansr.pt/SegurancaRodoviaria/ArtigosTecnicos/Documents/Risco\%20nas\%20estradas\%2 00\%20papel\%20do\%20g\%C3\%A9nero\%20na\%20seguran\%C3\%A7a\%20rodovi\%C3\%A1ria.pdf, accessed on May 2015.

ANSR (Autoridade Nacional de Segurança Rodoviária), Relatório Nacional Annual 2014, http://www.ansr.pt/Estatisticas/RelatoriosDeSinistralidade/Documents/2014/RELAT\%C3\%93RIO\%20 ANUAL\%20V\%C3\%8DTIMAS\%20A\%2024\%20HORAS/Relat\%C3\%B3rio\%20Anual\%20Sinistralidad e\%20Rodovi\%C3\%A1ria\%202014.pdf, accessed on May 2015.

BURNS, A. and BUSH, R. (2006). Marketing Research. $5^{\text {a }}$ edição. New Jersey, Prentice Hall.

CARDOSO, P. and FONSECA, M. J. (2012). Campanhas portuguesas de prevenção rodoviária: uma análise da sua influência. Verso e Reverso, 26(62), 62-71.

DOBSON, A., BROWN, W., BALL, J., POWERS, J. and MCFADDEN, M. (1999). Women drivers' behavior, socio-demographic characteristics and accidents. Accident Analysis and Prevention, 31, pp. 525535.

DELHOMME, P., DOBBELEER, W., FORWARD, S. and SIMÕES, A. (2009). Manual for designing, implementing and evaluating road safety communication campaigns. Brussels, Belgian Road Safety Institute.

ESTRATÉGIA NACIONAL DE SEGURANÇA RODOVIÁRIA 2008-2015, http://www.ansr.pt/SegurancaRodoviaria/PlanosdeSegurancaRodoviaria/Documents, accessed on December 2014. 
EUROPEAN TRANSPORT SAFETY COUNCIL, Risk on the Roads - A Male Problem? (PIN Flash 25) 2013, http://etsc.eu/risk-on-the-roads-a-male-problem-pin-flash-25/, accessed on December 2014.

FONSECA, M. J. (2012). PhD thesis: As campanhas de comunicação de marketing no âmbito da prevenção rodoviária portuguesa: um contributo para a análise da sua eficácia. Porto, Universidade Fernando Pessoa.

GEORGE, D. and MALLERY, P. (2003). SPSS for Windows step by step: A simple guide and reference. (4th ed.). Boston: Allyn \& Bacon.

HOLLAND, C., GERAGHTY, J., and SHAH, K. (2010). Differential moderating effect of locus of control on effect of driving experience in young male and female drivers. Personality and individual differences, 48(7), pp. 821-826.

INE (Instituto Nacional de Estatística) Censos 2011, http://censos.ine.pt, accessed on December 2014.

LANCASTER, R., and WARD, R. (2002). The contribution of individual factors to driving behaviour: Implications for managing work-related road safety. HM Stationery Office.

LANDAU, S. and EVERITT, B. S. (2004). A handbook of statistical analyses using SPSS. Florida: Chapman \& Hall/CRC Press LLC.

LEWIS, I., WATSON, B. and WHITE, K. (2008). An examination of message-relevant affect in road safety messages: should road safety advertisements aim to make us feel good or bad? Transportation Research Part F: Traffic Psychology and Behaviour, 11(6), pp. 403-417.

LEWIS, I., WATSON, B., WHITE, K. and TAY, R. (2007a). Promoting public health messages: should we move beyond fear-evoking appeals in road safety? Qualitative Health Research, 17(1), pp. 61-74.

LEWIS, I., WATSON, B., TAY, R. and WHITE, K. (2007b). The role of fear appeals in improving driver safety: a review of the effectiveness of fear-arousing (threat) appeals in road safety advertising. International Journal of Behavioral and Consultation Therapy, 3(2), pp. 203-222.

MARQUES, C. (2011). Dissertação de Mestrado - A influência da publicidade na segurança rodoviária. Lisboa, Escola Superior de Comunicação Social, Instituto Politécnico de Lisboa.

MOWEN, J., HARRIS, E. and BONE, S. (2004). Personality traits and fear response to print advertisements: theory and an empirical study. Psychology \& Marketing, 21(11), pp. 927-943.

OLTEDAL, S., and RUNDMO, T. (2006). The effects of personality and gender on risky driving behaviour and accident involvement. Safety Science, 44(7), pp. 621-628.

ÖZKAN, T., and LAJUNEN, T. (2006). What causes the differences in driving between young men and women? The effects of gender roles and sex on young drivers' driving behaviour and selfassessment of skills. Transportation Research Part F: Traffic Psychology and Behaviour, 9(4), pp. 269-277.

PALLANT, J. (2005). SPSS survival manual: a step by step guide to data analysis using SPSS. Crows Nest, Allen \& Unwin.

PEIXOTO, A. (2006). Estudo Sociológico - Sinistralidade rodoviária. Da evidência à realidade. Ponta Delgada, Edições Macaronésia. 
PLANO NACIONAL DE PREVENÇÃO RODOVIÁRIA (2003). http://www.ansr.pt, accessed on December 2014.

POLLAY, R. and MITTAL, B. (1993). Here's the beef: factors, determinants, and segments in consumer criticism of advertising. Journal of Marketing, 57, pp. 99-114.

QUIVY, R. and CAMPENHOUDT, L. (2008). Manual de investigação em ciências sociais. $5^{\mathrm{a}}$ edição. Lisboa, Gradiva.

RETO, L. and SÁ, J. (2003). Porque nos matamos na estrada e como o evitar. Um estudo sobre o comportamento dos condutores. Lisboa, Editorial Notícias.

SHINAR, D., SCHECHTMAN, E., and COMPTON, R. (2001). Self-reports of Safe Driving Behaviours in Relationship to Sex, Age, Education and Income in the US Driving Population. Accident Analysis and Prevention, 33, pp. 243 - 255.

TAY, R. (2002). Exploring the effects of a road safety advertising campaign on the perceptions and intentions of the target and nontarget audiences to drink and drive. Traffic Injury Prevention, 3, pp. 195-200.

TURNER, C., and MCCLURE, R. (2003). Age and gender differences in risk-taking behaviour as an explanation for high incidence of motor vehicle crashes as a driver in young males. Injury control and safety promotion, 10(3), pp. 123-130.

WALLER, P., ELLIOT, M., SHOPE, J., RAGHUNATHAN, T., and LITTLE, R. (2001). Changes in Young Adults Offence and Crash Patterns Over Time. Accident Analysis and Prevention. 33, pp. 117 - 128.

WIMMER, R. and DOMINICK, J. (1996). La investigación científica de los medios de comunicación. Barcelona, Bosch.

WORLD HEALTH ORGANIZATION. Global status report on road safety: time for action 2009, http://apps.who.int/iris/bitstream/10665/44122/1/9789241563840_eng.pdf, accessed on May 2014. 